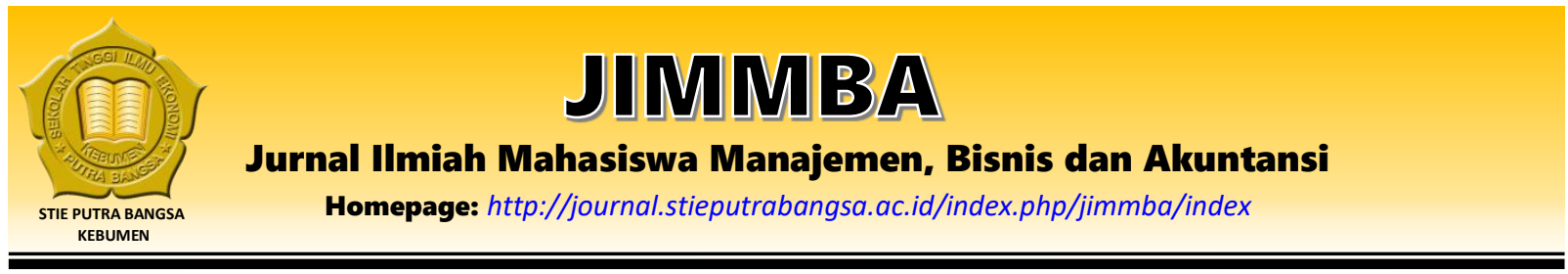

\title{
Menguji Intention to Use E-Wallet OVO Menggunakan Modifikasi Technology Acceptance Model (TAM) di Kebumen
}

\author{
Ifa Noviatun ${ }^{1}$, Sulis Riptiono ${ }^{2}$ \\ 1, 2 Sekolah Tinggi Ilmu Ekonomi Putra Bangsa \\ Email: Iffanoviatun@gmail.com ${ }^{1}$
}

ARTICLE INFO

Article History:

Received: April 12th 2021

Accepted: April 26 2021

Published: May 5 2021

Keywords:

Perceived Risk, Perceived

Ease of Use, Perceived

Usefulness, Intention to Use

\begin{abstract}
Tujuan penelitian ini adalah mengetahui pengaruh perceived risk terhadap intention to use melalui perceived ease of use dan perceived usefulness sebagai variabel intervening pada penggunaan e-wallet OVO transportasi online Grab di Kebumen. Populasi pada penelitian ini adalah pengguna transportasi online Grab di Kebumen yang belum pernah menggunakan e-wallet OVO. Penelitian ini menggunakan metode purposive sampling dengan sampel sebanyak 100 responden. Berdasarkan metode statistika dilakukan uji validitas, uji reabilitas, uji asumsi klasik (uji multikonieritas, uji heteroskedastisitas, dan uji normalitas), uji parsial, uji koefisien determinasi, dan analisis jalur. Hasil penelitian ini menunjukan bahwa berdasarkan uji validitas dan reabilitas semua variabel dinyatakan valid dan reliabel. Berdasarkan hasil uji $\mathrm{t}$ sub struktur I variabel perceived risk berpengaruh negatif terhadap perceived ease of use. Hasil uji $t$ sub struktur II variabel perceived risk berpengaruh negatif terhadap perceived usefulness, perceived ease of use berpengaruh positif terhadap perceived usefulness. Kemudian untuk sub struktur III variabel perceived risk berpengaruh negatif terhadap intention to use, perceived ease of use tidak berpengaruh terhadap intention to use, perceived usefulness berpengaruh positif terhadap intention to use.
\end{abstract}

\section{Pendahuluan}

Transportasi online merupakan salah satu produk dari perkembangan teknologi informasi yang tidak dapat dihindari (David 2018). Transportasi online telah mengubah kebiasaan dan sistem sosial dalam masyarakat. Awalnya masyarakat menggunakan cara yang konvensional untuk menggunakan transportasi umum, saat ini masyarakat mulai mengubah kebiasaaan mereka dan beralih ke teknologi komunikasi untuk memesan transportasi secara online. Dengan menggunakan transportasi online, proses transaki menjadi lebih cepat dan mudah sehingga akan lebih efisien. Untuk itu, trasportasi online sudah mulai dikenal dan diterima oleh publik dan juga dipandang bermanfaat bagi masyarakat (Ihsanuddin, 2017). Sebanyak 95\% konsumen merasa aman ketika menggunakan transportasi umum berbasis online (Aziza, 2017). 
Pentingnya meneliti transportasi online lebih mendalam, terutama dikarenakan zaman telah memasuki era revolusi industri 4.0 dengan trend bisnis digital, yang ditandai dengan perkembangan big data dan artificial intelligence (Surya, 2019). Bahkan diperkirakan pada tahun 2025 perusahaan atau industri akan menuju era autonomous business, di mana perusahaan atau industri harus bertransformasi dari proses manual menuju digital (Putra, 2018). Selain itu, transportasi sendiri merupakan jantung aktivitas serta mobilitas manusia setiap harinya. Transportasi juga berperan penting dalam kelangsungan ekonomi, politik, sosial-budaya, pertahanan, keamanan, pariwisata (Marlina dan Natalia, 2017), hingga kualitas kehidupan manusia (Steg dan Gifford, 2005).

Grab merupakan jasa layanan transportasi online yang berasal dari luar negeri. Ide bisnis ini muncul ketika mereka melihat adanya dampak negatif dari tidak efisiennya sistem transportasi yang ada pada saat itu. Grab menyediakan layanan di Asia Tenggara yaitu Singapura, Filipina, Malaysia, Thailand, Vietnam, Myanmar, Kamboja, dan Indonesia (Saputri, 2019). Grab melayani banyak sekali fitur seperti: Grab Taxi, Grab Car, Grab Share, Grab Bike, Grab Express, Grab Food, Grab Hitch Bike dan Grab Hitch Car. Grab pada awal didirikan pada tahun 2012 dalam pembayaran masih menggunakan transaksi konvensional berupa uang tunai, tetapi seiring berkembangnya teknologi Grab mulai menggunakan transaksi digital berupa Grab Pay, selanjutnya pada tahun 2018 sistem pembayaran digital Grab Pay disempurnakan dengan platform baru yang bernama e-wallet OVO (Fajar et al., 2019).

E-wallet OVO muncul di era cashless society yang memudahkan penggunanya dalam bertransaksi non tunai. E-wallet OVO adalah sejumlah dana yang berbentuk uang elektronik yang dapat diakses melalui aplikasi $e$-wallet OVO yang mampu dipergunakan sebagai media pembayaran atau transaksi keuangan, dengan menawarkan sistem $e$-wallet yang praktis dan menjadi aplikasi keuangan yang dapat bekerja secara berkesinambungan dan misi sosial yang ingin dikembangkan $e$-wallet $\mathrm{OVO}$ dalam mendukung program pemerintah terkait dengan GNNT (Gerakan Nasional Non Tunai) (Diah et.al., 2020).

Riset yang dilakukan oleh lembaga riset berbasis aplikasi "Snapcart" pada bulan Mei 2019 dengan responden pengguna dompet digital di kota- kota besar di Indonesia, hasil menunjukan bahwa dalam segmen transportasi online dan pemesanan makan online, $e$ wallet OVO dengan layanan Grab merupakan dompet digital terfavorit dalam bertransaksi ini, sedangkan rivalnya dari Go-Jek yaitu Go-Pay transasksinya masih dibawah e-wallet OVO. Dengan perbandingan nilai $71 \%$ responden lebih niat menggunakan e-wallet OVO untuk pemesanan transportasi atau pemesanan makanan online dan $29 \%$ untuk $e$-wallet GoPay (Idris, 2019). Adapun e-wallet OVO telah bekerja sama dengan 500 ribu merchant di 300 kota di Indonesia sedangkan Go-Pay sudah bekerja sama dengan 300 ribu merchant di Indonesia (Cindy, 2019)

Keberadaan e-wallet OVO pada masa pandemic covid- 19 sekarang ini, sangat membantu masyarakat dalam melakukan physhical distancing atau jaga jarak untuk memutuskan rantai penyebaran virus yaitu dengan melakukan pembayaran secara non tunai. Seperti yang sudah diketahui bahwa dalam masa pandemi ini diharapkan kepada masyarakat untuk mengurangi transaksi secara tunai karena dapat memicu terjadinya penularan covid- 19 melalui perpindahan uang dari tangan ke tangan. Maka, dengan menggunakan pembayaran cashless masyarakat sudah ikut berpartisipasi dalam melawan virus corona. Selain itu dengan menggunakan e-wallet OVO pastinya lebih aman, mengurangi drama uang kembalian dan banyak diskon serta promo menarik. Tidak hanya itu, dengan melakukan pembayaran digital melalui e-wallet OVO pada Grab mudah untuk dipelajari dan digunakan 
dikarenakan hanya dengan satu kali klik untuk mengganti metode pembayaran dan saldo pada e-wallet OVO terpotong secara automatis (Diah et.al., 2020).

Salah satu teori yang digunakan untuk mengukur tingkat penerimaan dari suatu teknologi yaitu metode TAM. Technology Acceptance Model (TAM) merupakan sebuah alat teoritis yang baik, populer, dan menawarkan suatu penjelasan yang kuat dan sederhana untuk mempelajari penerimaan dan penggunaan teknologi (Handayani dan Harsono, 2016). TAM diperkenalkan pertama kali oleh Davis pada tahun 1989. Tujuan lain dari TAM adalah untuk menjelaskan dan memprediki penerimaan pengguna terhadap suatu teknologi (Sutomo, 2008). TAM dapat memprediksi penerimaan pengguna terhadap teknologi berdasarkan pengaruh dari dua faktor, yaitu persepsi manfaat (perceived usefulness) dan persepsi kemudahan penggunaan (perceived ease of use) (Davis, dalam Morris dan Dillon, 1997) namun seiring berjalannya waktu ditambahkan persepsi risiko (perceived risk) (Oentario et.al., 2017).

Berdasarkan survei terbuka yang dilakukan oleh penulis kepada 30 responden responden yang niat menggunakan $e$-wallet OVO yaitu : menunjukan bahwa sebanyak 11 responden atau 37\% menggunakan e-wallet OVO karena faktor perceived east of use (persepsi kemudahan). Responden menyatakan, bahwa dengan menggunakan e-wallet OVO lebih mudah untuk digunakan dan lebih fleksibel (tidak memerlukan uang cash). Kemudian sebanyak 10 responden atau 33\% menggunakan e-wallet OVO dipengaruhi oleh faktor perceived risk (persepsi resiko), responden menyatakan, bahwa menggunakan e-wallet OVO terdapat persepsi mengenai adanya resiko biaya dan resiko kemananan. Sebanyak 9 responden atau $30 \%$ menggunakan e-wallet OVO karena faktor perceived usefulness (persepsi manfaat dan kegunaan). Responden menyatakan, bahwa menggunakan e-wallet OVO menjadi lebih praktis, efektif, dan sangat mempermudah pengguna apabila ingin melakukan transaksi selain membayar Grab.

\section{Kajian Teori dan Telaah Literatur}

\section{Intention to Use}

Menurut Davis et.al (1989) niat perilaku atau menggunakan yaitu tingkat seberapa kuat keinginan atau dorongan seseorang untuk melakukan perilaku tertentu. Menurut Fishbein dan Ajzen dalam Purnomo dan Haryanto, 2011) intention to use atau niat penggunaan yaitu kekuatan seseorang untuk menggunakan sesuatu. Dalam penelitian ini, peneliti menggunakan indikator intention to use menurut Jogiyanto (2007), yaitu: keinginan untuk menggunakan, ingin mencoba untuk menggunakan, akan menggunakan dimasa yang akan datang.

\section{Perceived Usefulness}

Menurut Jogiyanto (2008) mengemukan, definisi persepsi kemanfaatan sebagai sejauh mana individu yakin dengan menggunakan teknlogi akan mengingkatkan kinerja pekerjaanya. menurut Lavenia dan Irawan (2018), persepsi kemanfaatan (perceived usefulness) yang didefinisikan sebagai sejauh mana seseorang yakin bahwa menggunakan sistem akan meningkatkan kinerjanya. Menurut Shun Wang et.al (2003); Mahardhika (2019) persepsi kemanfaatan merupakan definisi dimana seseorang percaya bahwa dengan menggunakan suatu sistem tertentu maka akan dapat meningkatkan kinerja mereka. Dalam penelitian ini. peneliti menggunakan indikator perceived usefulness menurut Davis et.al (1989) yaitu: pekerjaan lebih cepat, peningkatan kinerja, peningkatan produktivitas, peningkatan efektivitas, memudahkan dalam pekerjaan, memberikan manfaat. 


\section{Perceived Ease of Use}

Menurut Davis (1989) kemudahan penggunaan yang dipersepsikan didefinisikan sebagai sejauh mana seseorang percaya bahwa mengunakan suatu teknologi akan ada bebas dari usaha. Menurut Jogiyanto (2008) perceived ease of use adalah tingkat keprcayaan seseorang terhadap teknologi yang mudah dipahami dan mudah digunakan bagi pengguna sistem tersebut. Menurut Turban et al, (2010) perceived ease of use sebaiknya dapat digunakan semudah mungkin tanpa melalui proses yang mempersulit para penggunanya. Pengguna sistem informasi mempercayai bahwa sistem informasi yang lebih fleksibel, mudah dipahami dan mudah pengoperasiaanya sebagai karakteristik kemudahan penggunaan. Dalam penelitian ini, peneliti menggunakan indikator perceived ease of use menurut Istiarni (2014) yaitu: mudah dipelajari dan penggunaanya fleksibel, sistem dapat mengerjakan dengan mudah apa yang diinginkan oleh pengguna, penggunaan mudah serta pengefisiensian waktu, mudah dioperasikan.

\section{Perceived Risk}

Menurut Schiffman dan Kanuk (2008:170) risiko yang dirasakan merupakan ketidakpastian yang dihadapi para konsumen jika mereka tidak dapat meramalkan konsekuensi keputusan pembelian mereka. Menurut Javenpra et al (2000) dalam Pavlow (2003:78), persepsi resiko memainkan peranan yang kuat untuk mengurangi niat konsumen untuk mengambil bagian dalam kegiatan bertransaksi sehingga persepsi resiko dimungkinkan akan berpengaruh negatif untuk melakukan transaksi atau merupakan ekspektasi subyektif dari konsumen tentang kerugian yang mungkin akan terjadi dalam upaya mencapai hasil yang diinginkan. Dalam penelitian ini, peneliti menggunakan indikator perceived risk menurut Utami (2016), yaitu: tingginya risiko, keamanan bertransaksi, keamanan sistem.

\section{Kerangka Pemikiran}

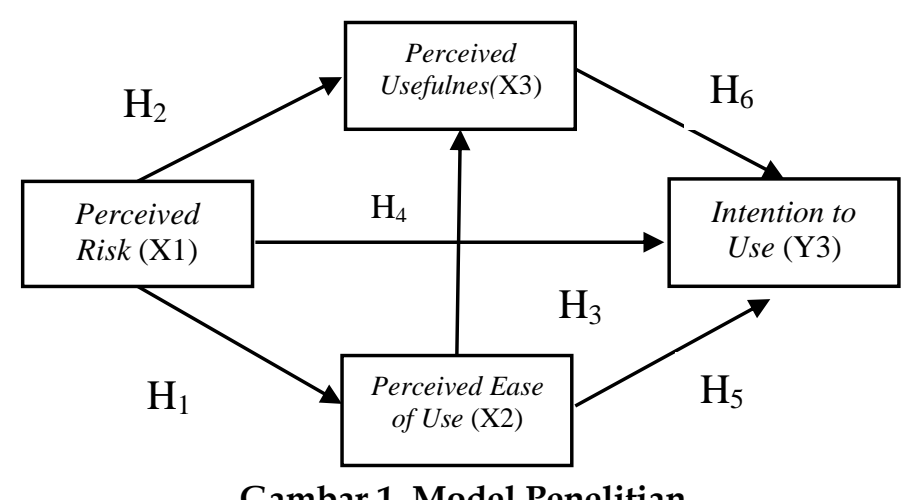

Gambar 1. Model Penelitian

\section{Metode Penelitian}

\section{Objek dan Subjek Penelitian}

Obyek yang digunakan dalam penelitian ini adalah perceived risk (sebagai variabel independen), perceived ease of use dan perceived usefulness (sebagai variabel intervening), dan intention to use (sebagai variabel dependen). Subyek dalam penelitian ini adalah pengguna transportsai online Grab di kebumen yang belum pernah menggunakan $e$-wallet OVO. 


\section{Populasi dan Sampel}

Populasi pada penelitian ini adalah pengguna transportasi online Grab di Kebumen yang belum pernah menggunakan $e$-wallet OVO. Sampel dalam penelitian ini adalah pengguna transportasi online Grab di Kabupaten Kebumen yang belum pernah menggunakan $e$-wallet OVO dengan kriteria berusia minimal 18 tahun.

\section{Teknik dan Analisis Data}

Teknik analisis data yang digunakan dalam penelitian ini adalah menggunakan SPSS 26 for windows (Statistical

Product and Services Solution dengan dilakukan Uji Validitas, Uji Reabilitas, Uji Asumsi Klasik, Uji Hipotesis, dan Analisis Jalur.

\section{Hasil dan Pembahasan}

\section{Uji parsial (uji t)}

Tabel 1. hasil uji t substruktural 1

\begin{tabular}{|c|c|c|c|c|c|}
\hline \multicolumn{6}{|c|}{ Coefficients $^{a}$} \\
\hline \multirow{3}{*}{ Model } & \multirow{2}{*}{\multicolumn{3}{|c|}{$\begin{array}{lc} & \text { Standardiz } \\
\text { ardized } & \text { ed } \\
\text { cients } & \text { Coefficien } \\
& \text { ts }\end{array}$}} & \multirow{3}{*}{$\mathbf{t}$} & \multirow{3}{*}{ Sig. } \\
\hline & & & & & \\
\hline & B & Std. Error & Beta & & \\
\hline 1 (Constant) & 14,352 & 737 & & 19,483 & ,000 \\
\hline $\begin{array}{l}\text { Perceived } \\
\text { Risk }\end{array}$ &,- 264 & 107 &,- 241 & $-2,457$ & ,016 \\
\hline a. Dependen & Jariable & Perceived E & se of Use & & \\
\hline
\end{tabular}

Sumber: Data primer diolah (2020)

Tabel 2. hasil uji t substruktural 2

\begin{tabular}{|c|c|c|c|c|c|}
\hline \multicolumn{6}{|c|}{ Coefficients $^{a}$} \\
\hline \multirow[t]{2}{*}{ Model } & \multicolumn{2}{|c|}{$\begin{array}{l}\text { Unstandardized } \\
\text { Coefficients }\end{array}$} & \multirow{2}{*}{$\begin{array}{c}\begin{array}{c}\text { Standardize } \\
\mathrm{d}\end{array} \\
\text { Coefficients }\end{array}$} & \multirow[t]{2}{*}{$\mathbf{t}$} & \multirow[t]{2}{*}{ Sig. } \\
\hline & B & $\begin{array}{l}\text { Std. } \\
\text { Error }\end{array}$ & & & \\
\hline 1 (Constant) & 16,527 & 1,962 & & 8,422 & ,000 \\
\hline $\begin{array}{l}\text { Perceived } \\
\text { Risk }\end{array}$ &,- 288 & 134 &,- 205 & $-2,152$ & ,034 \\
\hline $\begin{array}{l}\text { Perceived } \\
\text { Ease of Use }\end{array}$ & ,394 & 122 & 309 & 3,233 & ,002 \\
\hline a. Dependent & riable: $\mathrm{Pe}$ & eived L & sefulness & & \\
\hline
\end{tabular}


Tabel 3. hasil uji t substruktural 3

\begin{tabular}{|c|c|c|c|c|c|c|}
\hline \multicolumn{7}{|c|}{ Coefficients $^{\mathrm{a}}$} \\
\hline & \multirow[t]{2}{*}{ Model } & \multicolumn{2}{|c|}{$\begin{array}{l}\text { Unstandardize } \\
\text { d Coefficients }\end{array}$} & \multirow{2}{*}{$\begin{array}{c}\begin{array}{c}\text { Standar } \\
\text { dized }\end{array} \\
\begin{array}{c}\text { Coeffici } \\
\text { ents }\end{array} \\
\text { Beta }\end{array}$} & \multirow[t]{2}{*}{$\mathbf{T}$} & \multirow[t]{2}{*}{ Sig. } \\
\hline & & B & $\begin{array}{l}\text { Std. } \\
\text { Error }\end{array}$ & & & \\
\hline \multirow[t]{4}{*}{1} & (Constant) & 6,760 & 1,409 & & 4,799 & ,000 \\
\hline & $\begin{array}{l}\text { Perceived } \\
\text { Risk }\end{array}$ &,- 212 & ,075 &,- 268 & $-2,836$ & ,006 \\
\hline & $\begin{array}{l}\text { Perceived } \\
\text { Ease of Use }\end{array}$ & ,085 & ,070 & 118 & 1,212 & 228 \\
\hline & $\begin{array}{l}\text { Perceived } \\
\text { Usefulness }\end{array}$ & 144 & ,055 & ,256 & 2,604 & ,011 \\
\hline \multicolumn{7}{|c|}{ a. Dependent Variable: Intention to Use } \\
\hline
\end{tabular}

\section{Pembahasan}

Variabel perceived risk berpengaruh signifikan terhadap perceived usefulness pada penggunaan $e$-wallet OVO transportasi online Grab di Kebumen. Hasil kuesioner menunjukan bahwa sebagian besar responden beranggapan $e$-wallet OVO memiliki sistem keamanan yang rendah. Hal tersebut didasarkan pada indikator keamanan bertransaksi, dimana beberapa responden berargumen bahwa menggunakan $e$-wallet OVO sering terjadi hilangnya saldo dan gagal pengisan saldo, sehingga dapat dikatakan bahwa layanan tersebut tidak aman atau mempunyai resiko yang tinggi. Pengguna mungkin khawatir dengan risiko yang akan diperoleh ketika melakukan transaksi, sehingga ketika pengguna merasa resikonya tinggi, maka akan mengurangi persepsi kegunaan dari $e$-wallet OVO.

Variabel perceived risk berpengaruh secara signifikan terhadap perceived ease of use pada penggunaan $e$-wallet OVO transportasi online Grab di Kebumen. Hasil kuesioner menunjukan bahwa sebagian besar responden memiliki argumen bahwa menggunakan e-wallet OVO mempunyai risiko yang tinggi. Persepsi risiko sangat berkaitan erat dengan kemudahan pada penggunaan layanan. Hasil negatif berkaitan dengan pertanyaan dalam kuesioner yang menyatakan sistem dapat mengerjakan dengan mudah apa yang diinginkan oleh pengguna atau kemudahan yang rendah pada $e$-wallet OVO, sehingga ketika konsumen merasa kemudahan yang diberikan rendah maka hasilnya negatif, oleh karena itu risiko yang tinggi menggambarkan adanya kemudahan yang rendah mengenai penggunaan $e$-wallet OVO.

Variabel perceived risk berpengaruh secara signifikan terhadap perceived ease of use pada penggunaan $e$-wallet OVO transportasi online Grab di Kebumen. Hasil kuesioner menunjukan bahwa risiko menjadi salah satu faktor yang mempengaruhi niat untuk mengadopsi layanan $e$ wallet. Semakin tinggi risiko yang dimiliki, maka akan mengurangi niat untuk menggunakan layanan tersebut. Risiko yang dimiliki pengguna terhadap layanan $e$-wallet berawal dari risiko yang mereka miliki terhadap pihak transportasi online dan risiko yang dimiliki dapat mengurangi niat untuk menggunakan $e$-wallet OVO.

Variabel perceived usefulness berpengaruh secara signifikan terhadap perceived ease of use pada penggunaan e-wallet OVO transportasi online Grab di Kebumen. Kemudahan dalam penggunaan layanan $e$-wallet OVO dapat memberikan penilaian bahwa menggunakan $e$ wallet OVO memiliki manfaat dan kegunaan yang tinggi untuk membantu pengguna dalam bertransaksi. Hal tersebut didasarkan pada indikator penggunaan mudah serta pengefisiensian 
waktu, dimana sebagian besar responden memberikan penilaian yang tinggi dan merasakan kemudahan dalam menggunakan layanan $e$-wallet OVO sehingga dapat memenuhi kebutuhan mereka dalam melakukan transaksi.

Variabel perceived usefulness tidak berpengaruh secara signifikan terhadap intention to use pada penggunaan $e$-wallet OVO transportasi online Grab di Kebumen. Hasil kuesioner menunjukkan bahwa beberapa responden memberikan penilaian yang rendah terhadap perceived usefulness. Tinggi atau rendahnya persepsi mengenai kegunaan yang terdapat pada $e$-wallet OVO bukanlah faktor yang mendorong niat untuk menggunakan, dengan kata lain perceived usefulness bukanlah faktor yang dapat meningkatkan niat untuk menggunakan $e$ wallet OVO dalam kehidupan sehari-hari secara terus-menerus. Berdasarkan hasil penelitian ini, terdapat variabel lain yang lebih dominan dalam mempengaruhi niat untuk menggunakan $e$-wallet OVO.

Variabel perceived ease of use berpengaruh secara signifikan terhadap intention to use pada e wallet OVO transportasi online Grab di Kebumen. Hasil kuesioner menunjukan bahwa responden memberikan penilaian yang tinggi terhadap perceived ease of use pada penggunaan $e$-wallet OVO transportasi Grab di Kebumen. Hal terseebut didasarkan pada indikator mudah dioperasikan, dimana sebagian besar responden memberikan penilaian yang tinggi dan menganggap bahwa menggunakan e wallet OVO sangat fleksibel tidak membutuhkan keahlian kusus sehingga akan mudah untuk mengoperasikannya. Persepsi kemudahan yang tinggi cenderung akan mendukung perubahan yang terjadi dalam niat untuk menggunakan. Semakin tinggi perceived ease of use semakin besar pula kemungkinan pengguna untuk niat menggunakan e-wallet OVO. Sehingga dapat dikatakan bahwa perceived ease of use merupakan salah satu faktor utama dalam niat untuk mengadopsi $e$-wallet OVO.

\section{Penutup dan Saran}

Risiko merupakan salah satu faktor yang menghambat seseorang niat untuk menggunakan suatu produk, karena setiap orang cenderung menghindari adanya risiko. Pengguna yang memiliki banyak informasi dan pengalaman akan memiliki persepsi yang berbeda dengan pengguna yang masih baru dan memiliki sedikit informasi. Oleh karena itu penting bagi perusahaan jasa untuk meminimalisir adanya risiko yang akan dirasakan oleh pengguna mengenai produk tersebut.

Persepsi manfaat atau kegunaan merupakan faktor yang mempengaruhi niat menggunakan suatu produk. Terbentuknya persepsi yang tepat pada konsumen akan menumbuhkan kesan yang baik dan memberikan penilaian yang tepat, sehingga persepsi yang dimiliki konsumen akan membuat ia tertarik untuk membeli atau menggunakan suatu produk. Jadi konsumen akan memutuskan untuk membeli jika dirasa manfaat dari produk tersebut itu tinggi.

Persepsi kemudahan merupakan faktor yang mempengaruhi niat menggunakan suatu produk. Terbentuknya persepsi yang tepat pada konsumen akan menumbuhkan kesan yang baik dan memberikan penilaian yang tepat, sehingga persepsi yang dimiliki pengguna akan membuat ia niat untuk membeli atau menggunakan suatu produk. Jadi konsumen akan niat menggunakan jika dirasa kemudahan dari produk tersebut tinggi. 


\section{Referensi}

Aziza, K. S. (2017). Mengapa Masyarakat Lebih Suka Memilih Transportasi 'Online'?. Kompas. com, Jakarta.

Azmi, A. A. C., Kamarulzaman, Y., \& Hamid, N. H. A. (2012). Perceived risk and the adoption of tax e-filing. World Applied Sciences Journal, 20(4), 532-539.

Christina, H., Suhud, U., \& Rizan, M. (2018). Analisis penerimaan dan penggunaan teknologi ojek online dengan tam. Jurnal Pendidikan Ekonomi Dan Bisnis (JPEB), 6(1), 34-44.

David, D. (2018). Pengaruh E-service Quality terhadap Loyalitas Pelanggan melalui Kepuasan Pelanggan pada Transportasi Online Grab. Agora, 6(2).

Davis, F. D. (1989). Perceived usefulness, perceived ease of use, and user acceptance of information technology. MIS Q. 13(3), 319

Fajar, B. M., Lutfiyani, L., \& Mirati, T. (2019). Menelusuri Faktor-Faktor yang Mempengaruhi Minat Penggunaan OVO Pada Pelanggan Grab Mahasiswa IAIN Surakarta Fakultas Ekonomi Dan Bisnis Islam. Academica: Journal of Multidisciplinary Studies, 3(1), 109122.

Featherman, M. S., \& Pavlou, P. A. (2003). Predicting e-services adoption: a perceived risk facets perspective. International journal of human-computer studies, 59(4), 451-474.

Handayani, W. P. P., \& Harsono, M. (2016). Aplikasi technology acceptance model (TAM) pada komputerisasi kegiatan pertanahan. Jurnal Economia, 12(1), 13-22.

Istiarni, P. R. D., \& Hadiprajitno, P. B. (2014). Analisis pengaruh persepsi manfaat, kemudahan penggunaan dan kredibilitas terhadap minat penggunaan berulang internet banking dengan sikap penggunaan sebagai variabel intervening (studi empiris: nasabah layanan internet banking di Indonesia). Doctoral dissertation, Fakultas Ekonomika dan Bisnis.

Jarvenpaa, S. L., \& Staples, D. S. (2000). The use of collaborative electronic media for information sharing: an exploratory study of determinants. The Journal of Strategic Information Systems, 9(2-3), 129-154.

Jogiyanto, H.M., 2007. Sistem Informasi Keperilakuan. Yogyakarta:Andi.

Lavenia, B. C., Iqbal, M., \& Irawan, A. (2018). Pengaruh Technology Acceptance Model (Tam) Dan Electronic Word Of Mouth (Ewom) Terhadap Kepuasan Pelanggan (Survei Pada Pelanggan Go-Jek Di Kota Kediri). Jurnal Administrasi Bisnis, 60(3), 5261.

Mahardhika, A. S. (2019). Akuntan Di Era Digital: Pendekatan TAM (Technology Acceptance Model) Pada Software Berbasis Akuntansi. Jurnal Ilmiah Akuntansi dan Keuangan, 8(1), 12-16.

Marlina, E., \& Natalia, D. A. (2017). Land Transportation and Tourism Development. International Journal of Economic Perspectives, 11(2).

Oentario, Y., Harianto, A., \& Irawati, J. (2017). Pengaruh Usefulness, Ease of Use, Risk Terhadap Intentionto Buy Onlinepatisserie Melalui Consumer Attitude Berbasis Media Sosial Di Surabaya. Jurnal Manajemen Pemasaran, 11(1), 26-31. 
Praveena, K., \& Thomas, S. (2014). Continuance intention to use Facebook: A study of perceived enjoyment and TAM. Bonfring International Journal of Industrial Engineering and Management Science, 4(1), 24-29.

Saputri, R. S. D. (2019). Pengaruh Kualitas Pelayanan dan Harga Terhadap Loyalitas Pelanggan Grab Semarang. CoverAge: Journal of Strategic Communication, 10(1), 46-53.

Saraswati, P. D. S. (2020). Determinan Minat Penggunaan E-Wallet OVO Pada Transportasi Online Grab (Doctoral dissertation, Universitas Pendidikan Ganesha).

Schiffman, L., \& Kanuk, L. L. (2008). Perilaku konsumen edisi ketujuh. Jakarta: PT Index Group.

Steg, L., \& Gifford, R. (2005). Sustainable transportation and quality of life. Journal of transport geography, 13(1), 59-69.

Surya, A. P. (2019). Customer Loyalty from Perspective Of Marketing Mix Strategy and Customer Satisfaction a Study from Grab-Online Transportation in Era of Industrial Revolution 4.0. MIX: Jurnal Ilmiah Manajemen, 9(3), 293232.

Sutomo, D. (2012). Pengaruh Perceived Ease Of Use, Perceived Usefulness, dan Perceived Risk Terhadap Intention to Transact Pada Toko Online di Surabaya. Kajian Ilmiah Mahasiswa Manajemen, 1(1), 30-34.

Wang, Y. S., Wang, Y. M., Lin, H. H., \& Tang, T. I. (2003). Determinants of user acceptance of Internet banking: an empirical study. International journal of service industry management, 14(5), 501-519. 